\title{
SISTEM INFORMASI PERKULIAHAN ONLINE PADA FAKULTAS ILMU KOMPUTER UNIVERSITAS MUHAMMADIYAH METRO LAMPUNG
}

\author{
Sudarmaji ${ }^{1}$, Kurniawan Adi Prasetyo ${ }^{2}$ \\ Fakultas IImu Komputer Universitas Muhammadiyah Metro Lampung ${ }^{1}$, \\ Teknisi Universitas Muhammadiyah Metro Lampung ${ }^{2}$ \\ Kampus 3 Jalan Gatot Subroto No. 100 Yosodadi Kota Metro Lampung
}

e-mail: majidarma5022@gmail.com ${ }^{1}$,

\begin{abstract}
Abstrak
Sistem informasi yang sedang berjalan dan hasil perancangan yang baru dari perancangan Sistem Informasi Perkuliahan Online Pada Fakultas IImu Komputer Universitas Muhammadiyah Metro Kota Metro yang menggunakan database, dan menghasilkan sebuah antarmuka perkuliahan antara dosen dan mahasiswa.

Secara garis besar penulis dapat mengemukakan bahwa sebagian sistem informasi yang sedang berjalan belum cukup baik, karena terdapat kekurangan dalam sistem tersebut, yaitu sistem siakad dan e-learning yang tidak menjadi satu, sehingga dinilai kurang efisien dalam sistem perkuliahan sebuah universitas. Penelitian menggunakan metode pengolahan data berupa observasi, interview, dan dokumentasi. Sedangkan metode perancangan aplikasi menggunakan Bagan Alir Dokumen, Data Flow Diagram, Entity Relationship Diagram. Software pendukung dalam pembuatan website ini ialah adobe dreamweaver cs 6, bahasa pemrograman php dan database mariaDB.Sistem Informasi Perkuliahan Online menghasilkan rancangan berupa rancangan database/basis data yaitu tabel perkuliahan, dosen, mahasiswa, status, forum. Entity Relationship Diagram (ERD) dan Relasi antar tabel. Rancangan antar muka yaitu login, halaman utama, halaman mahasiswa, halaman forum, halaman nilai dan halaman status.

Dari perancangan aplikasi ini diharapkan dapat memperbaiki sistem perkuliahan yang berjalan pada Fakultas IImu Komputer Universitas Muhammadiyah Metro.
\end{abstract}

Kata kunci: Sistem Informasi, Perkuliahan Online, e-learning, Database, Antarmuka

\begin{abstract}
Ongoing information systems and new design results from the design of Information Systems Online Lectures At the Faculty of Computer Science, Muhammadiyah Metro Metro University using database, and produce a lecture interface between lecturers and students. In general, the authors can argue that adobe some of the information systems that are running is not good enough, because there are deficiencies in the system, namely siakad system and e-learning that does not become one, so it is considered less efficient in a university lecture system. The research used data processing methods in the form of observation, interview, and documentation. While the method of application design using Document Flow Chart, Data Flow Diagram, Entity Relationship Diagram. Software support in making this website is dreamweaver cs 6, php programming language and database mariaDB.Sistem Information Online Lecture generate design in the form of database design / database that is table lecture, lecturer, student, status, forum. Entity Relationship Diagram (ERD) and Relation between tables. Interface design is login, main page, student page, forum page, value page and status page. From the design of this application is expected to improve the lecture system that runs on the Faculty of Computer Science University Muhammadiyah Metro.
\end{abstract}

Keywords: Information System, Online lecture, e-learning, Database, Interface 


\section{PENDAHULUAN}

Perkembangan teknologi informasi dan komunikasi sampai dengan saat ini begitu pesatnya seiring waktu berjalan, bahkan begitu banyak orang diseluruh dunia bergantung pada teknologi yang berkembang. Sistem infomasi perkuliahan online adalah cara baru dalam proses belajar mengajar yang merupakan dasar dan konsekuensi logis dari perkembangan teknologi informasi dan komunikasi. Dengan perkuliahan online, peserta ajar (learner atau mahasiswa) tidak perlu duduk di ruang kelas untuk menyimak setiap ucapan dari seorang dosen secara langsung.

Perkuliahan online juga dapat mempersingkat jadwal target waktu perkuliahan, dan tentu saja menghemat biaya yang harus dikeluarkan oleh sebuah program studi atau program pendidikan. Perkuliahan online mempermudah interaksi antara mahasiswa dengan bahan/materi, mahasiswa dengan dosen/instruktur maupun sesama mahasiswa. Mahasiswa dapat saling berbagi informasi dan dapat mengakses bahanbahan belajar setiap saat dan berulangulang, dengan kondisi yang demikian itu dapat lebih memantapkan penguasaannya terhadap materi pembelajaran.

\section{A. Aliran informasi Sistem informasi akademik Berjalan}

Dalam hal ini yang dimaksud adalah aktivitas dan kegiatan objek-objek yang terkait dalam pengolahan data materi perkuliahan seperti, nilai ujian, nilai quis dan nilai tugas sehingga menghasilkan Kartu Hasil Studi, aliran sistem informasi akademik pada Fakultas IImu Komputer Universitas Muhammadiyah Metro yang sedang berjalan serta pihak-pihak yang terlibat

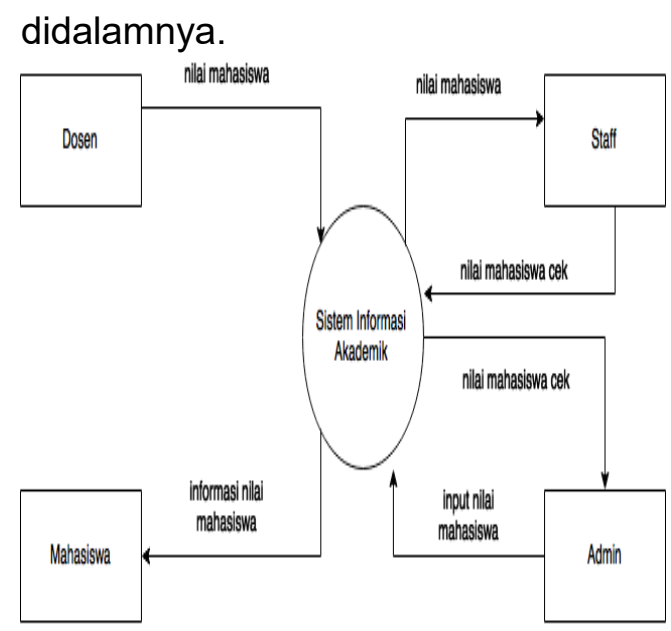

Gambar 1. Diagram Konteks Sistem Informasi Akademik

B. Data Flow Diagram Sistem Informasi Akademik Berjalan

Data flow diagram sistem informasi akademik pada diploma-III Universitas Muhammadiyah Metro yang sedang berjalan serta pihak-pihak yang terlibat di dalamnya.

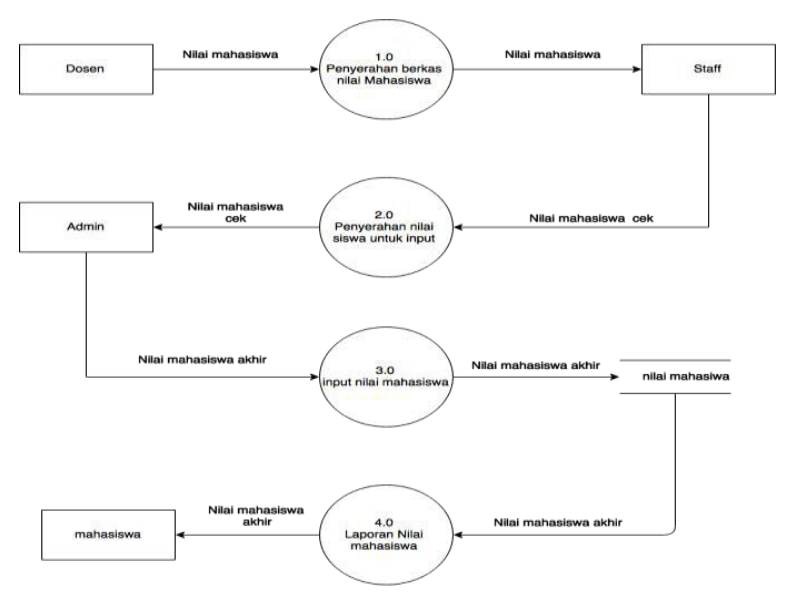

Gambar 2 Data Flow Diagram Sistem Informasi Akademik

C. Aliran Informasi E-Learning Berjalan Aliran informasi e-learning dimulai dengan dosen yang memberikan file kepada admin, kemudian admin dapat mengupload file materi tersebut ke website untuk dapat diakses oleh mahasiswa, aliran e-learning pada diploma-III Universitas Muhammadiyah Metro yang sedang berjalan serta pihak-pihak yang terlibat di dalamnya. 


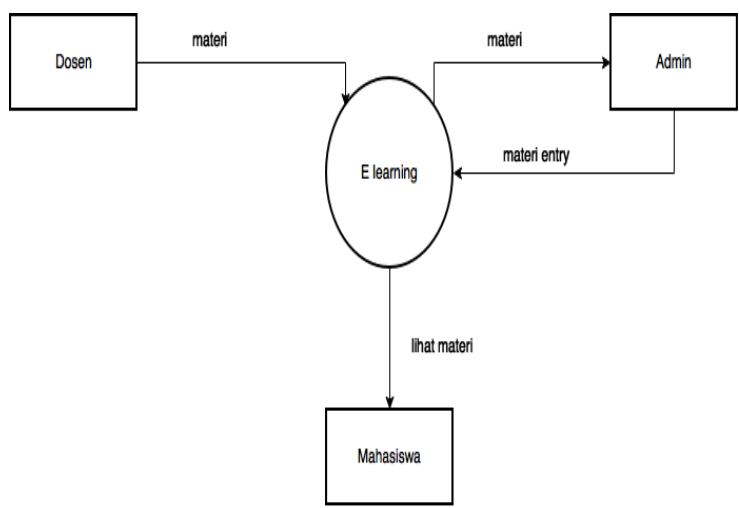

Gambar 3 Diagram Konteks E-Learning

\section{KAJIAN TEORI}

\section{A. Sistem Informasi}

Sistem informasi merupakan suatu perkumpulan data yang terorganisasi beserta tatacara penggunaanya yang mencangkup lebih jauh dari pada sekedar penyajian. Istilah tersebut menyir atkan suatu maksud yang ingin dicapai dengan jalan memilih dan mengatur data serta menyusun tatacara penggunaanya.Keberhasilan suatu sistem informasi yang diukur berdasarkan maksud pembuatanya tergantung pada tiga faktor utama, yaitu : keserasian dan mutu data, pengorganisasian data, dan tatacara penggunaanya.untuk memenuhi permintaan penggunaan tertentu, maka struktur dan cara kerja sistem informasi berbeda-beda ber gantung pada macam keperluan atau macam permintaan yang harus dipenuhi. Suatu persamaan yang menonjol ialah suatu sistem informasi menggabungkan berbagai ragam data yang dikumpulkan dari berbagai sumber.

Menurut A-bahra bin Ladjamudin (2013:13) "sistem informasi adalah suatu sistem yang dibuat oleh manusia yang terdiri dari komponen-komponen dalam organisasi untuk mencapai suatu tujuan yaitu menyajikan informasi". Menyangkut pemahaman tentang pengertian sistem informasi ini, dalam bukunya, Agus Mulyanto (2009:29) mengutipkan beberapa pendapat para ahli, diantaranya:

1. Menurut James alter, sistem informasi adalah "kombinasi antar prosedur kerja, informasi, orang dan teknologi informasi yang diorganisasikan untuk mencapai tujuan dalam sebuah organisasi".

2. Menurut Bodnar dan Hopwood, sistem informasi adalah "kumpulan perangkat keras dan perangkat lunak yang dirancang untuk mentransformasikan data ke dalam bentuk informasi yang berguna".

3. Menurut Gelinas, Oram dan Wiggins, sistem informasi adalah "suatu sistem buatan manusia yang secara umum terdiri atas sekumpulan komponen berbasis komputer dan manual yang dibuat untuk menghimpun, menyimpan, dan mengelola data serta menyediakan informasi keluaran kepada pemakai".

4. Menurut Turban, McLean dan Waterbe, sistem informasi adalah "sistem yang mengumpulkan, memproses, menyimpan, menganalisis, dan mneyebarkan informasi untuk tujuan spesifik".

Sistem informasi adalah suatu sistem di dalam suatu organisasi yang mempertemukan kebutuhan pengolahan transaksi harian yang mendukung fungsi operasi organisasi yang bersifat manajerial dengan kegiatan strategi dari suatu organisasi untuk dapat menyediakan kepada pihak luar tertentu dengan laporan-laporan yang diperlukan.

\section{B. Sistem E-learning}

E-Learning atau pembelajaran elektronik pertama kali diperkenalkan oleh Universitas Ilionis di UrbanaChampaign dengan menggunakan sistem instruksi berbasis komputer (Computer Assisted Instruktion) dan komputer bernama PLATO.Sejak saat itu, perkembangan E-Learning berkembang sejalan dengan perkembangan dan kemajuan teknologi. Berikut perkembangan E-Learning dari masa ke masa :

a. Tahun 1990 : Pada masa Computer-Based Training (CBT) di mana mulai bermunculan aplikasi E-Learning yang berjalan dalam PC standlone ataupun berbentuk 
kemasan CD-ROM. Isi materi dalam bentuk tulisan maupun multimedia (Video dan Audio) dalam format mov, mpeg-1, atau avi.

b. Tahun 1994 : Seiring dengan diterimanya CBT oleh masyarakat sejak tahun 1994 CBT muncul dalam bentuk paket-paket yang lebih menarik dan diproduksi secara masal.

c. Tahun 1997 : Learning Management System (LMS). Seiring dengan perkembangan teknologi internet, masyarakat di dunia mulai terkoneksi dengan internet. Kebutuhan akan informasi yang dapat diperoleh dengan cepat mulai dirasakan sebagai kebutuhan mutlak dan jarak serta lokasi bukanlah halangan lagi. Dari sinilah muncul LMS. Perkembangan LMS yang makin pesat membuat pemikiran baru untuk mengatasi masalah interoperability antar LMS yang satu dengan lainnya secara standar. Bentuk standar yang muncul misalnya standar yang dikeluarkan oleh Airline Industry CBT Commettee (AICC), IMS, IEEE LOM, ARIADNE. Tahun 1999 sebagai tahun aplikasi E-learning berbasis Web. Perkembangan LMS menuju aplikasi e-learning berbasis Web berkembang secara total, baik untuk pembelajar (learner) maupun administrasi belajar mengajarnya. LMS mulai digabungkan dengan situs-situs informasi, majalah dan surat kabar. Isinya juga semakin kaya dengan perpaduan multimedia, video streaming serta penampilan interaktif dalam berbagai pilihan format data yang lebih standar dan berukuran kecil.

E-learning adalah suatu sistem atau konsep pendidikan yang memanfaatkan teknologi informasi dalam proses belajar mengajar. Berikut beberapa pengertian E-learning dari berbagai sumber:

1. Pembelajaran yang disusun dengan tujuan menggunakan sistem elektronik atau komputer sehingga mampu mendukung proses pembelajaran
(Michael, 2013:27).

2. Proses pembelajaran jarak jauh dengan menggabungkan prinsip-prinsip dalam proses pembelajaran dengan teknologi (Chandrawati, 2010).

3. Sistem pembelajaran yang digunakan sebagai sarana untuk proses belajar mengajar yang dilaksanakan tanpa harus bertatap muka secara langsung antara dosen dengan mahasiswa (Ardiansyah, 2013).

Manfaat Perkuliahan Online

Ada 3 (tiga) fungsi pembelajaran elektronik terhadap kegiatan pembelajaran di dalam kelas (Classroom instruction), yaitu sebagai suplemen yang sifatnya pilihan/optional, pelengkap (komplemen), atau pengganti (substitusi) .

a. Suplemen

Dikatakan berfungsi sebagai supplemen (tambahan), apabila mahasiswa mempunyai kebebasan memilih, apakah akan memanfaatkan materi pembelajaran elektronik atau tidak. Dalam hal ini, tidak ada kewajiban/keharusan bagi mahasiswa untuk mengakses materi pembelajaran elektronik. Sekalipun sifatnya opsional, mahasiswa yang memanfaatkannya tentu akan memiliki tambahan pengetahuan atau wawasan.

b. Komplemen (Tambahan)

Dikatakan berfungsi sebagai komplemen (pelengkap) apabila materi pembelajaran elektronik diprogramkan untuk melangkapi materi pembelajaran yang diterima mahasiswa di dalam kelas. Sebagai Komplemen berarti materi pembelajaran elektronik diprogramkan utnuk menjadi materi reinforcement (pengayaan) atau remedial bagi mahasiswa di dalam mengikuti kegiatan pembelajaran konvensional. Materi pembelajaran elektronik dikatakan sebagai enrichment, apabila kepada mahasiswa yang dapat dengan cepat menguasai/memahami materi pelajaran yang disampaikan dosen secara tatap muka (+9) diberikan kesempatan untuk mengakses materi pembelajaran elektronik yang memang secara khusus 
dikembangkan untuk mahasiswa. Tujuannya agar semakin memantapkan tingkat penguasaan mahasiswa terhadap materi pelajaran yang disajikan dosen didalam kelas. Dikatakan sebagai program perbaikan, apabila kepada mahasiswa yang mengalami kesulitan memahami materi pelajaran yang disajikan dosen secara tatap muka di kelas (Slow learners) diberikan kesempatan untuk memanfaatkan materi pembelajaran elektronik yang memang secara khusus dirancang untuk mahasiswa.

c. Pengganti (Substitusi)

Beberapa perdosenan tinggi di Negaranegara maju memberikan beberapa alternatif model kegiatan pembelajaran / perkuliahan kepada para mahasiswanya. Tujuannya agar para mahasiswa dapat secara fleksibel mengelola kegiatan perkuliahannya

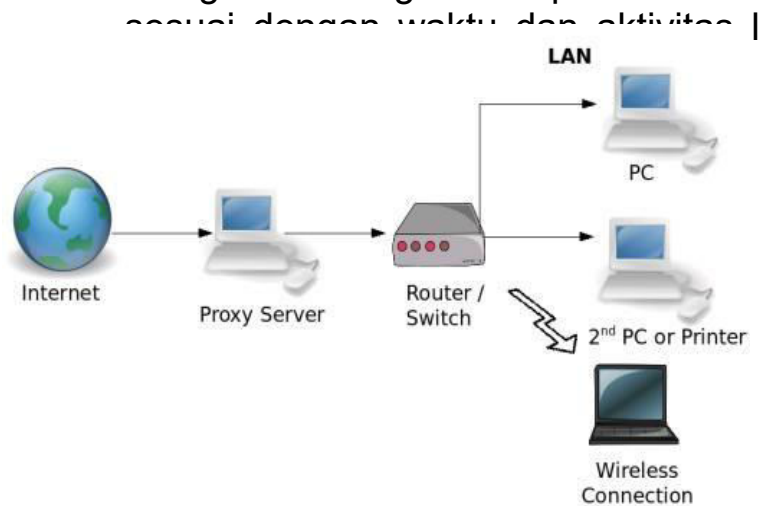

Gambar 4. Cara kerja internet. Sumber.

\section{METODOLOGI}

\section{A. Analisis Sistem}

Pada Gambar tabel 5 berikut ini menggambarkan rancangan diagram konteks sistem informasi perkuliahan online serta pihak-pihak yang terlibat di dalamnya.

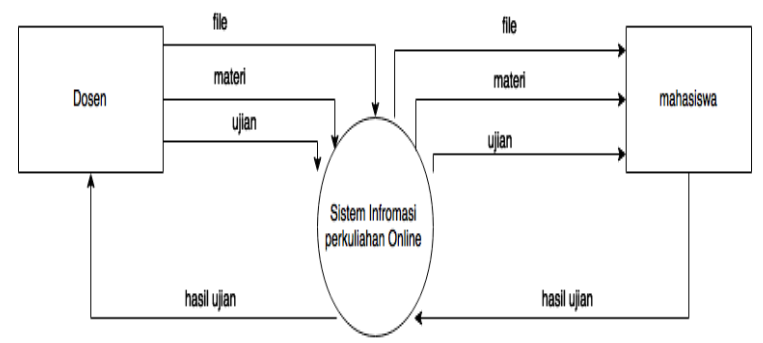

\section{Gambar 5 Diagram Konteks sistem informasi perkuliahan online}

Basisdata atau database adalah kumpulan file atau tabel untuk kaitannya dengan program ini. Untuk menyimpan data Sistem Informasi Perkuliahan Online pada

Nama database : kuliah_online

Berikut adalah tabel-tabel dalam database kuliah_online :

Tabel $\overline{1}$ tabel-tabel dalam database Kuliah online

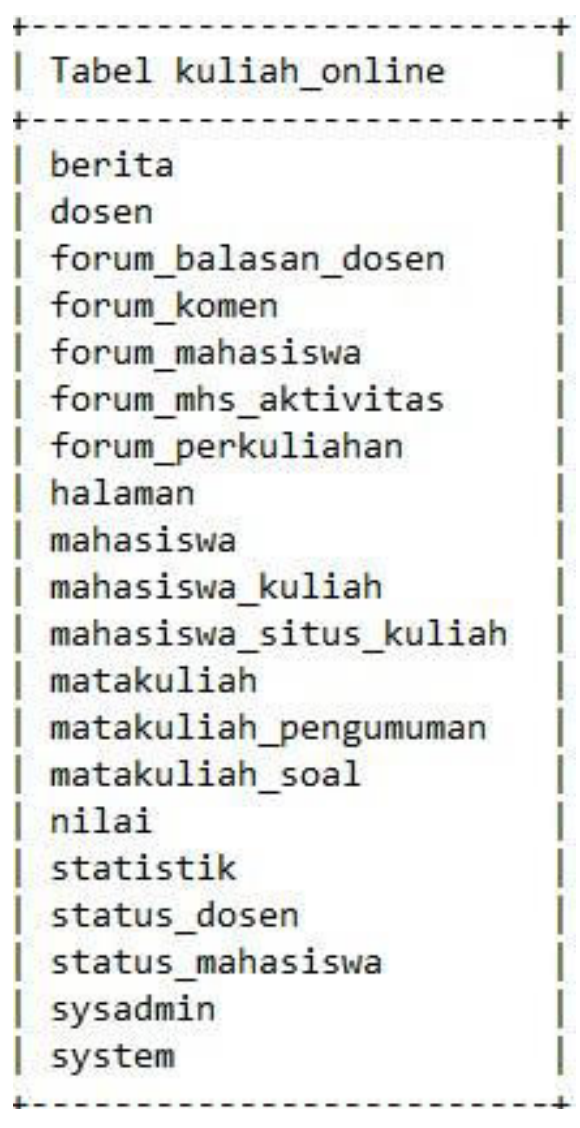

Tabel sysadmin befungsi untuk menyimpan data administrator website. Tabel sysadmin diperlukan untuk akses penuh di website. Berikut adalah stuktur tabel sysadmin.

Tabel 2 Tabel sysadmin 


\section{ISSN 2089-8673 (Print) | ISSN 2548-4265 (Online) \\ Volume 8, Nomor 1, Maret 2019}

\begin{tabular}{|c|c|c|c|c|c|}
\hline Field & | Type & Nul1 & Key & Default & | Extra \\
\hline id_sysadmin & $\operatorname{int}(11)$ & NO & PRI & NULL & auto_increment \\
\hline logsys & varchar (20) & YES & & NULL & \\
\hline passys & varchar (20) & YES & & NULL & \\
\hline name & $\operatorname{varchar}(30)$ & YES & & NULL & \\
\hline datelog & date & YES & & NULL & \\
\hline
\end{tabular}

Tabel system befungsi untuk menyimpan data pengaturan sistem informasi. Tabel system diperlukan untuk mengatur logo dan nama halaman utama sistem informasi. Berikut adalah stuktur tabel system:

Tabel 3 Tabel system

Sumber : D3 MI UM Metro, 2015, data diolah

\begin{tabular}{|c|c|c|c|c|c|}
\hline Field & Type & Null & Key & Default & Extra \\
\hline id_system & $\operatorname{int}(11)$ & NO & PRI & NULL & auto_increment \\
\hline system_name & $\operatorname{varchar}(250)$ & YES & & NULL & \\
\hline content & $\operatorname{varchar}(250)$ & YES & & NULL & \\
\hline date & date & YES & & NULL & \\
\hline
\end{tabular}

\section{berita}

Tabel berita befungsi untuk menyimpan berita. Tabel system diperlukan untuk mengatur informasi penting dalam sistem informasi. Berikut adalah stuktur tabel system.

Tabel 4 Tabel berita Sumber : D3 MI UM Metro, 2015, data diolah

\begin{tabular}{|c|c|c|c|c|c|}
\hline Field & Type & Null & Key & Default & Extra \\
\hline \multicolumn{6}{|c|}{ 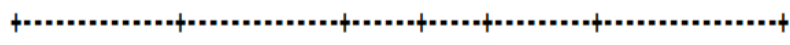 } \\
\hline id_berita & $\operatorname{int}(11)$ & | NO & PRI & NULL & auto_increment \\
\hline seo_berita & $\operatorname{varchar}(250)$ & YES & & NULL & \\
\hline juduI_berita & $\operatorname{varchar}(250)$ & YES & & NULL & \\
\hline isi_berita & text & YES & & NULL & \\
\hline tanggal & date & YES & & NULL & \\
\hline
\end{tabular}

\section{Tabel halaman}

Tabel 5 halaman befungsi untuk membuat halaman baru. Berikut adalah stuktur tabel halaman.

Tabel 5 Tabel halaman

Sumber : D3 MI UM Metro, 2015, data diolah

\begin{tabular}{|c|c|c|c|c|c|}
\hline | Field & Type & Null & Key & Default & Extra \\
\hline \multicolumn{6}{|c|}{ 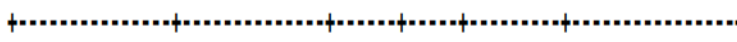 } \\
\hline | id_halaman & $\operatorname{int}(11)$ & No & | PRI & NULL & auto_increment \\
\hline seo_halaman & $\operatorname{varchar}(250)$ & YES & & NULL & \\
\hline judul_halaman & $\operatorname{varchar}(250)$ & YES & & NULL. & \\
\hline isi_halaman & text & YES & & NULL & \\
\hline tanggal & date & YES & & NULL. & \\
\hline
\end{tabular}

\section{Tabel statistik}

Tabel 6 Statistik berisikan data pengunjung yang login atau tanpa login di web . Berikut adalah struktur tabel statistik

Tabel 6 Tabel statistik data diolah

\begin{tabular}{|c|c|c|c|c|c|}
\hline Field & Type & Null & Key & Default & Extra \\
\hline \multicolumn{6}{|c|}{$\mid$} \\
\hline id_stat & $\operatorname{int}(5)$ & | NO & PRI & NULL & auto_increment \\
\hline ip_pengunjung & $\operatorname{varchar}(250)$ & NO & & NULL & \\
\hline browser_pengunjung & $\operatorname{varchar}(250)$ & No & & NULL. & \\
\hline tanggal_kujungan & date & NO & & NULL & \\
\hline
\end{tabular}

\section{Tabel mahasiswa}

Tabel mahasiswa berfungsi untuk mengolah data mahasiswa login ke sistem informasi pekuliahan. Berikut adalah struktur tabel mahasiswa

\section{Tabel 7 mahasiswa}

Sumber : D3 MI UM Metro, 2015, data diolah

\begin{tabular}{|c|c|c|c|c|c|}
\hline Field & | Type & | Nul1 & Key & Default & | Extra \\
\hline id_mahasiswa & int(11) & NO & PRI & NULL & auto_increment \\
\hline $\mathrm{npm}$ & $\operatorname{int}(8)$ & No & & NULL & \\
\hline password & $\operatorname{varchar}(25)$ & No & & NULL & \\
\hline nama_lengkap & $\operatorname{varchar}(30)$ & No & & NULL & \\
\hline alamat & text & YES & & NULL & \\
\hline no_hp & $\operatorname{int}(12)$ & YES & & NULL & \\
\hline email & $\operatorname{varchar}(50)$ & YES & & NULL & \\
\hline foto_profil & $\operatorname{varchar}(250)$ & YES & & NULL & \\
\hline nggal_lo & datetime & YES & & NULL & \\
\hline
\end{tabular}

\section{Tabel dosen}


Tabel dosen berfungsi untuk mengolah data dosen login ke sistem informasi pekuliahan. Berikut adalah struktur tabel dosen.

Tabel 8 Tabel dosen data diolah

Sumber : D3 MI UM Metro, 2015,

\begin{tabular}{|c|c|c|c|c|c|}
\hline | Field & | Type & | Null & | Key & | Default & | Extra \\
\hline id dosen & $\operatorname{int}(11)$ & N & DPT & WEII & auto increment \\
\hline nip & int(15) & No & $F_{1}$ & NULL. & duto__llitrement \\
\hline password & $\operatorname{varchar}(30)$ & No & & NULL & \\
\hline nama_dosen & $\operatorname{varchar}(30)$ & YES & & NULL. & \\
\hline alamat & text & YES & & NULL & \\
\hline no $h p$ & $\operatorname{int}(12)$ & YES & & NULL. & \\
\hline email & varchar (50) & YES & & NULL & \\
\hline fotopprofil & $\operatorname{int}(250)$ & YES & & NULL & \\
\hline tanggal_login & | datetime & | YES & & NULL & \\
\hline
\end{tabular}

\section{Tabel matakuliah}

Tabel matakuliah berfungsi sebagai pengolahan data matakuliah yang akan di ambil oleh mahasiswa peserta kuliah online. Berikut adalah struktur tabel matakuliah.

Tabel 9 Tabel matakuliah

\begin{tabular}{|c|c|c|c|c|c|}
\hline Field & Type & Null & Key & Default & Extra \\
\hline \multicolumn{6}{|c|}{ 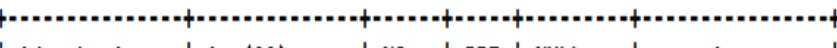 } \\
\hline id_mahasiswa & $\operatorname{int}(11)$ & NO & PRI & NULL & auto_increment \\
\hline npm & $\operatorname{int}(8)$ & NO & & NULL & \\
\hline password & $\operatorname{varchar}(25)$ & NO & & NULL & \\
\hline nama_lengkap & $\operatorname{varchar}(30)$ & NO & & NULL & \\
\hline alamat & text & YES & & NULL & \\
\hline no_hp & int(12) & YES & & NULL & \\
\hline email & $\operatorname{varchar}(50)$ & YES & & NULL & \\
\hline foto_profil & $\operatorname{varchar}(250)$ & YES & & NULL & \\
\hline tanggal_login & datetime & YES & & NULLL & \\
\hline
\end{tabular}

\section{Tabel mahasiswa_kuliah}

Tabel mahasiswa_kuliah berfungsi sebagai pengolahan data entri matakuliah mahasiswa. Berikut adalah tabel mahasiswa_kuliah.
Tabel 10 Tabel mahasiswa_kuliah

\begin{tabular}{|c|c|c|c|c|c|}
\hline | Field & | Type & Null & Key & Default & | Extra \\
\hline id_kelas & $\operatorname{int}(11)$ & NO & PRI & NULL & auto_increment \\
\hline id mahasiswa & $\operatorname{int}(11)$ & YES & & NULL & \\
\hline id_matakuliah & $\operatorname{int}(11)$ & YES & & NULL & \\
\hline
\end{tabular}

\section{Tabel matakuliah_pengumuman}

Tabel_matakuliah_pengumuman berfungsi sebagai pengolahan data pengumuman terbaru terkait matakuliah yang dientri oleh mahasiswa. Berikut adalah tabel matakuliah_pengumuman.

Tabel 11 Tabel matakuliah_pengumuman

\begin{tabular}{|c|c|c|c|c|c|}
\hline Field & Type & Null & Key & Default & Extra \\
\hline id_matpeng & $\operatorname{int}(11)$ & NO & PRI & NULL & auto_increment \\
\hline id_matakuliah & $\operatorname{int}(11)$ & YES & & NULL & \\
\hline seo_pengumuman & $\operatorname{varchar}(250)$ & YES & & NULLL & \\
\hline judul_pengumuman & $\operatorname{varchar}(250)$ & YES & & NULL & \\
\hline isi_pengumuman & text & YES & & NULLL & \\
\hline tanggal & date & YES & & NULL & \\
\hline
\end{tabular}

\section{Tabel matakuliah_soal}

Tabel matakuliah_soal berfungsi sebagai pengolahan data soal yang akan di berikan oleh dosen pengampu matakuliah kepada mahasiswa yang mengetri matakuliah. Berikut adalah struktur tabel matakuliah_soal

Tabel 12 Tabel matakuliah_soal

\begin{tabular}{|c|c|c|c|c|}
\hline Field & Type & Null | Key & Default & Extra \\
\hline \multicolumn{5}{|c|}{ 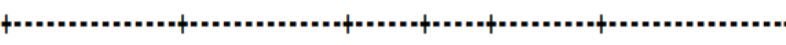 } \\
\hline id_soal & $\operatorname{int}(11)$ & | NO | PRI & NULL & auto_increment \\
\hline id_matakuliah & $\operatorname{int}(11)$ & YES & NULL & \\
\hline judul_soal & $\operatorname{varchar}(250)$ & YES & NULL & \\
\hline isi_soal & text & YES & NULL & \\
\hline type_soal & $\operatorname{int}(5)$ & YES & NULL & \\
\hline tanggal & date & YES | & NULL & \\
\hline
\end{tabular}




\section{Tabel nilai}

Tabel nilai berifungsi sebagai pengolahan data nilai mahasiswa setelah mahasiswa mengikuti perkuliahan online dan mengikuti latihan-latihan yang di berikan oleh dosen pengampu. Berikut adalah struktur tabel nilai

Tabel 13 Tabel nilai

Sumber : D3 MI UM Metro, 2015, data diolah

\begin{tabular}{|c|c|c|c|c|c|}
\hline Field & Type & Null & Key & Default & Extra \\
\hline 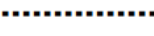 & ................... & $\cdots . .$. & 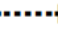 & (n....... & . \\
\hline id_nilai & $\operatorname{int}(11)$ & NO & PRI & NULL & auto_increment \\
\hline id_matakuliah & $\operatorname{int}(11)$ & YES & & NULL. & \\
\hline id_mahasiswa & $\operatorname{int}(11)$ & YES & & NULL. & \\
\hline nilai & $\operatorname{decimal}(5,2)$ & YES & & NULL & \\
\hline tanggal_input & date & YES & & NULL. & \\
\hline
\end{tabular}

\section{PEMBAHASAN}

\section{A. Relasi Data}

Relasi tabel menunjukkan hubungan antar tabel dalam sebuah database program. Relasi biasa ditunjukkan melalui sebuah diagram yakni ERD atau entity realtion data. Berikut adalah rancangan ERD :

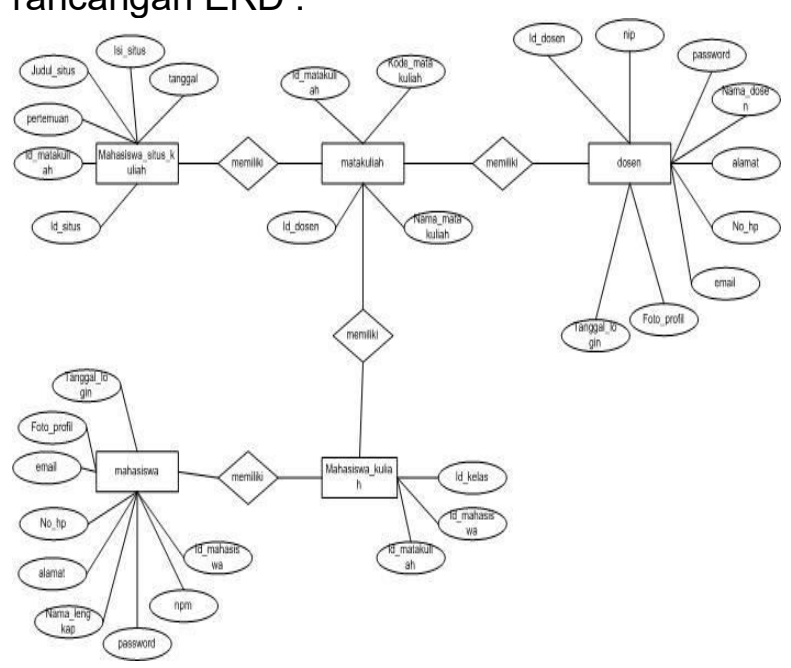

Gambar ERD Mata Kuliah

\section{B. Relasi Mata Kuliah}

Relasi Tabel untuk mata kuliah dapat dilihat pada gambar 6 di bawah ini:

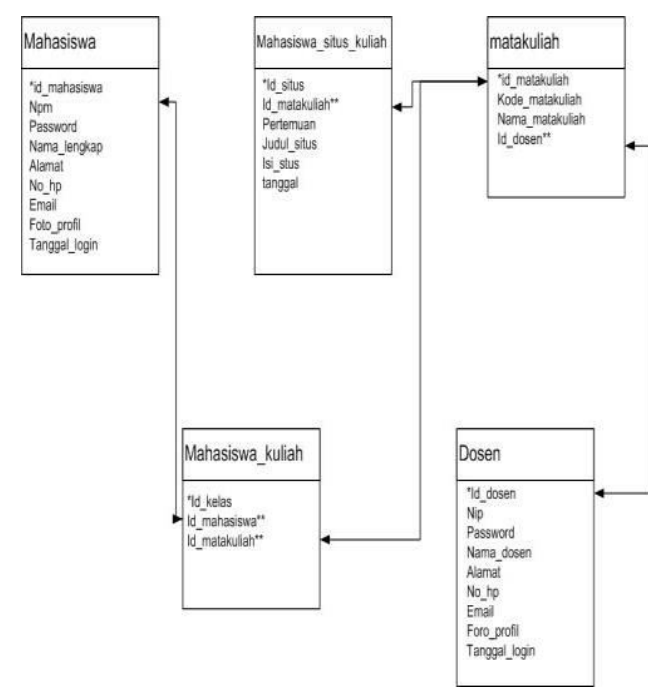

Gambar 6 Relasi Mata Kuliah

\section{Halaman Forum Matakuliah}

Halaman forum matakuliah ialah halaman yang digunakan untuk mahasiswa dan dosen dapat melakukan forum. Forum ini sebagai media komunikasi antar mahasiswa untuk melaksanakan proses perkuliahan.

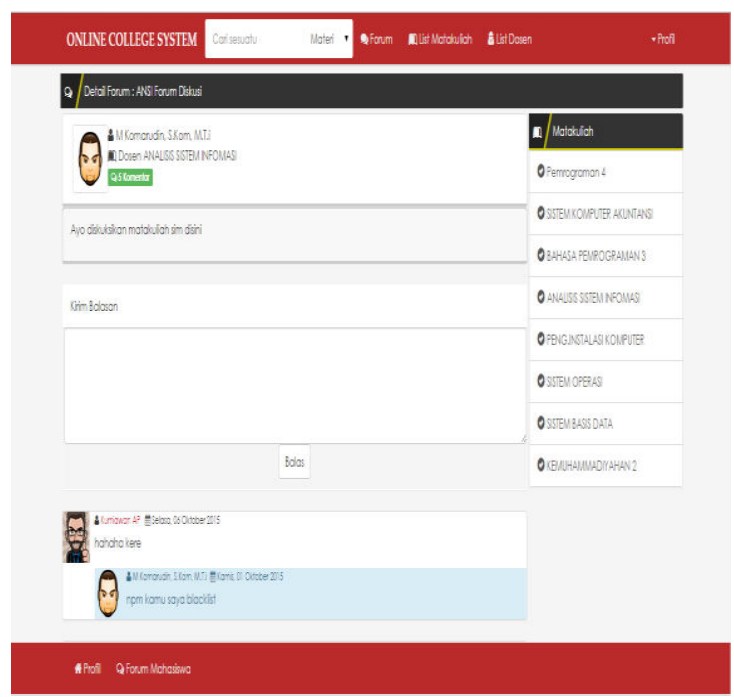

Gambar 7 tampilan halaman forum mata kuliah

\section{D. halaman edit profil mahasiswa}

Halaman edit profil mahasiswa ialah halaman yang digunakan untuk mengedit data mahasiswa. Berikut adalah tampilan halaman edit profil mahasiswa: 


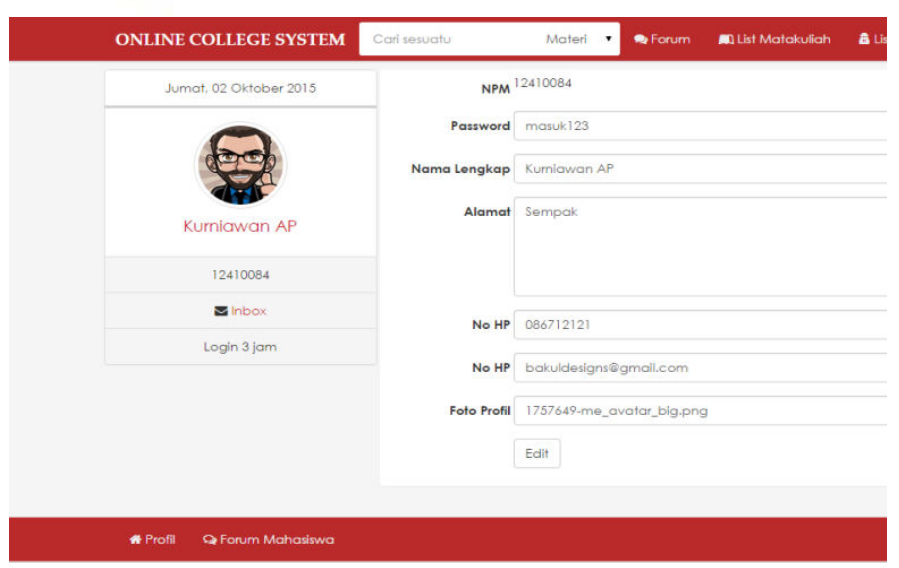

Gambar 8 tampilan halaman Edit profil mahasiswa

\section{E. Halaman Entry Mata Kuliah}

Halaman entry mata kuliah digunakan mahasiswa untuk memasukkan mata kuliah yang akan diikuti dalam satu semester. Berikut adalah tampilan halaman entry mata kuliah.

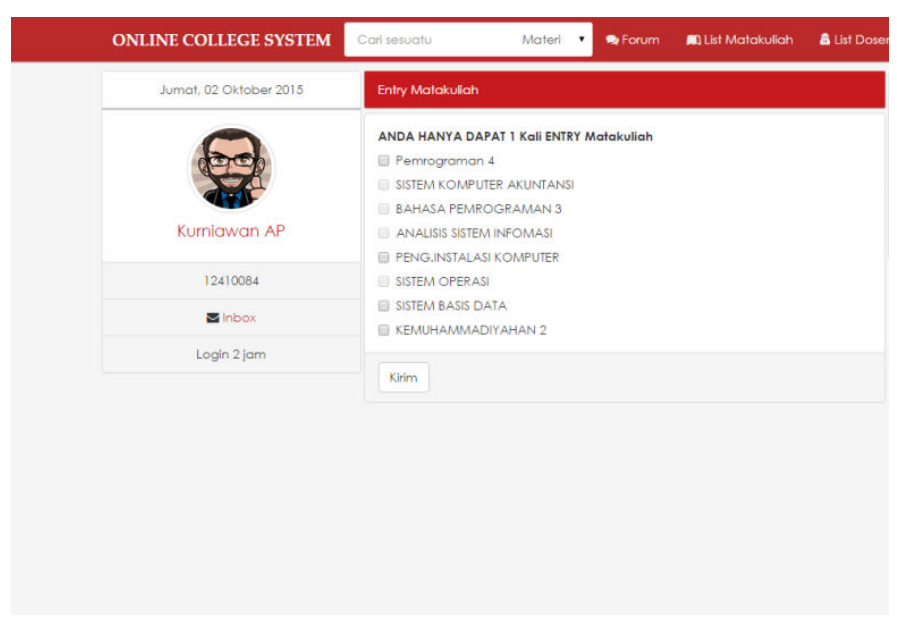

Gambar 9 tampilan halaman Entry Mata Kuliah

\section{F. Tampilan web mobile}

Tampilan web mobile adalah tampilan web saat diakses melalui ponsel. Berikut tampilan halaman web mobile.

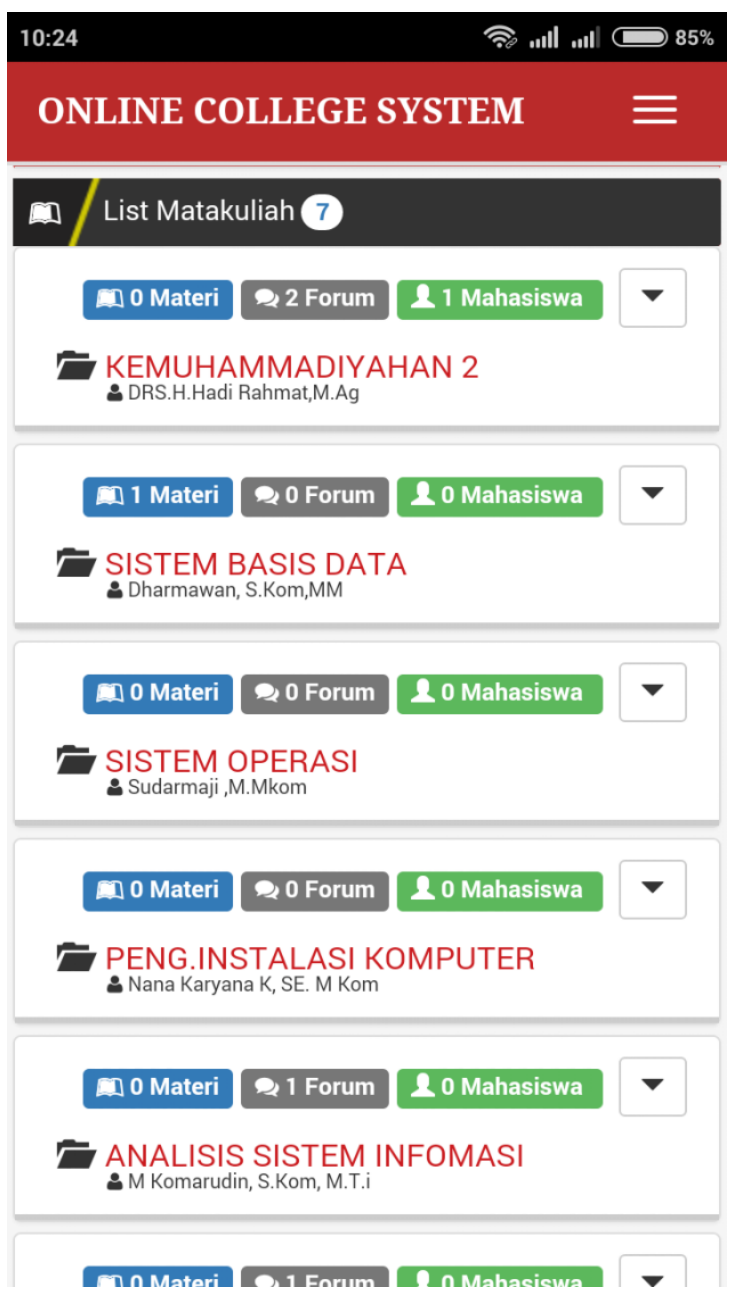

Gambar 10 tampilan halaman list tugas

\section{SIMPULAN}

Website dapat diakses dimanapun selama komputer terkoneksi dengan internet. Memudahkan dosen dalam berbagi materi dan file karena dosen hanya perlu mengunggah file tersebut ke website untuk diunduh oleh mahasiswa. Mahasiswa dapat langsung mengakses nilai, tugas, quis dan ujian sehingga dapat dilakukan dimana saja.

Informasi akan cepat tersebar melalui forum, sehingga komunikasi akan tetap berjalan walau mahasiswa atau dosen sedang jauh dari kampus. Berdasarkan analisis rancangan sistem informasi perkuliahan online pada Fakultas IImu Komputer Universitas Muhammadiyah Metro, dapat diambil beberapa kesimpulan sebagai berikut: 
1. Sistem informasi perkuliahan online dihasilkan rancangan login, rancangan input materi, forum diskusi, quis, tugas, dan ujian online, serta rancangan laporan nilai akhir.

2. Informasi yang dihasilkan lebih terstruktur di dalam penyajian antarmuka perkuliahan online.

3. Dengan adanya rancangan sistem yang baru tersebut diharapkan dapat membantu dosen dalam melakukan sharing materi, mengolah nilai dan membuat pengumuman, dan dapat membantu mahasiswa dalam mencari materi, pengumuman atau informasi nilai, dan berkomunikasi dengan mahasiswa.
[9] $\begin{array}{lr}\text { S Sudarmaji. (2017). } & \text { MODEL } \\ \text { PERANCANGAN } & \text { SISTEM } \\ \text { PENGOLAHAN } & \text { DATA }\end{array}$ ADMINISTRASI PADA FAKULTAS ILMU KOMPUTER UNIVERSITAS MUHAMMADIYAH METRO BERBASIS CLIENT SERVER. 7 (2)

\section{REFERENSI}

[1] Agus Mulyanto. 2009. Sistem Informasi Konsep dan Aplikasi. Pustaka Pelajar.

[2] Al-Bahra Bin Ladjamudin. 2013. Analisis dan Desain Sistem Informasi. Graha IImu. Yogyakarta.

[3] Anisyah. 2000. Analisa dan desain sistem informasi. PT. Andi offset. Yogyakarta.

[4] Budi Sutedjo dharma Oetomo. Perencanaan \& Pembangunan Sistem Informasi, Andi, Yogyakarta. 2002

[5] Buyens, Jim. 2001. Web database development. Elex media komputindo. Jakarta.

[6] Dhanta, risky. 2009. Kamus istilah komputer grafis dan internet. Indah. Surabaya.

[7] S Sudarmaji. (2017) istem Perkuliahan Online pada IAIN Raden Intan Bandar Lampung MIKROTIK: Jurnal Manajemen Informatika 7 (1)

[8] S Sudarmaji. (2016). Migrasi dan Optimalisasi Database Sistem Informasi berbasis E-Learning Program Diploma III Manajemen Informatika Universitas Muhammadiyah Metro. Mikrotik 6 (2) 